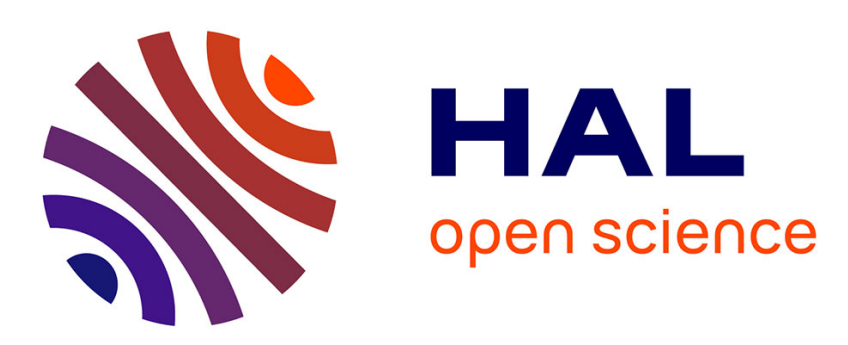

\title{
In-situ monitoring of the corrosion behaviour of austempered ductile iron (ADI) under cyclic salt spray exposure
}

H. Krawiec, V. Vignal, J. Lelito, A. Krystianiak, P. Ozga

\section{To cite this version:}

H. Krawiec, V. Vignal, J. Lelito, A. Krystianiak, P. Ozga. In-situ monitoring of the corrosion behaviour of austempered ductile iron (ADI) under cyclic salt spray exposure. Corrosion Science, 2021, 185, pp.109437. 10.1016/j.corsci.2021.109437 . hal-03410692

\section{HAL Id: hal-03410692 \\ https://hal.science/hal-03410692}

Submitted on 1 Nov 2021

HAL is a multi-disciplinary open access archive for the deposit and dissemination of scientific research documents, whether they are published or not. The documents may come from teaching and research institutions in France or abroad, or from public or private research centers.
L'archive ouverte pluridisciplinaire HAL, est destinée au dépôt et à la diffusion de documents scientifiques de niveau recherche, publiés ou non, émanant des établissements d'enseignement et de recherche français ou étrangers, des laboratoires publics ou privés. 


\title{
In-situ monitoring of the corrosion behaviour of austempered ductile iron (ADI) under cyclic salt spray exposure
}

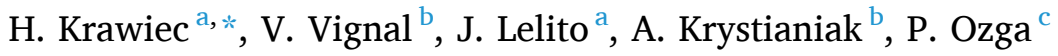 \\ ${ }^{a}$ AGH - University of Science and Technology, Faculty of Foundry Engineering, ul. Reymonta 23, 30-059, Krakow, Poland \\ ${ }^{\mathrm{b}}$ ICB, UMR 6303 CNRS - Université Bourgogne - Franche Comté, BP 47870, 21078, Dijon Cedex, France \\ ${ }^{\mathrm{c}}$ Polish Academy of Sciences, Institute of Metallurgy and Materials Science, 25 Reymonta Street, 30-059, Krakow, Poland
}

\section{A R T I C L E I N F O}

\section{Keywords:}

Salt fog

Corrosion

Austempered ductile iron

Pitting

Oxides

Microstructure

\begin{abstract}
A B S T R A C T
The corrosion behavior of austempered ductile iron (ADI) under cyclic salt spray exposure was studied using a specific three-electrode cell located in the salt fog chamber. Three steps were identified, namely pitting corrosion of ferrite (very first cycles), followed by inward oxidation of the ausferrite matrix and then (iii) mixed oxidation of the matrix associated with the formation of a rust layer at the specimen surface. Evolution of the corrosion rate calculated from in-situ electrochemical measurements was correlated with surface changes quantified from optical and field emission scanning electron (FE-SEM/EDS) microscopies. Corrosion products were identified by means of micro-Raman spectroscopy.
\end{abstract}

\section{Introduction}

In austempered ductile iron (ADI), graphite spheres are randomly distributed in a dual-phase matrix (ferrite ( $\alpha$-phase) and high carbon austenite (noted $\gamma_{\mathrm{HC}}$-phase)). This particular microstructure leads to good mechanical properties compared to ductile iron (high strength and good wear resistance, for example) [1-4]. ADI is then used in many industrial sectors (automotive and railroad industries, truck and bus components, construction and mining components, agricultural applications, defense sector...).

Several papers [5-9] have described the corrosion behaviour of ADI in bulk electrolyte solutions. In these papers, the influence of the elaboration parameters (tempering temperature, time of isothermal treatment,...), microstructure and physical-chemical parameters (nature of ions, temperature, $\mathrm{pH} . .$. ) has been studied and discussed. By contrast, the corrosion behavior of ADI under salt spray conditions has only been investigated according to ASTM B117 standard (continuous salt spray exposure) by means of weight loss measurements [10]. No electrochemical investigations have been performed after (continuous / cyclic) salt spray test exposure.

Specific cells have been designed to perform in-situ electrochemical measurements under salt spray conditions, in droplets and in thin electrolyte films. They have been applied to some metals (Fe [11], Zn [12,13], Cu [14], Mg [15]) and alloys (Fe-Ni [16], 316 L stainless steel
[17,18], 907 steel [19] and aluminum alloy 2024-T3 [20]), but not to ADI. In-situ electrochemical measurements offer several advantages over ex situ approaches (salt spray exposure followed by electrochemical measurements in the bulk electrolyte). The influence of the development / evaporation of the electrolyte film or droplets, the formation of corrosion products (dense or compact layers), the electrolyte flow... on corrosion mechanisms and kinetics can be investigated. In ex-situ approaches, corrosion products are modified by contact with air, there is no electrolyte flow...

The corrosion behavior of pure iron and various steels under atmospheric conditions has been addressed in numerous papers. These data may be useful to understand the behaviour of ADI. The reaction mechanisms of formation of corrosion products have been studied and discussed in review articles [21-25] and references therein]. Fe first dissolves to $\mathrm{Fe}^{2+}$ ions. These ions undergo hydrolysis (formation of $\mathrm{Fe}$ $(\mathrm{OH})^{+}$) and oxidation (formation of $\mathrm{Fe}^{3+}$ ions). $\mathrm{Fe}(\mathrm{OH})^{+}$can be quickly oxidized to $\mathrm{Fe}(\mathrm{OH})_{2}^{+}$, which then transforms into $\gamma$-FeO(OH) (lepidocrocite). $\mathrm{Fe}(\mathrm{OH})^{+}$can also be slowly oxidized to $\mathrm{Fe}_{\mathrm{a}}^{2+} \mathrm{Fe}_{\mathrm{b}}^{3+} \mathrm{O}_{\mathrm{x}}(\mathrm{OH})_{\mathrm{y}}$. This compound then transforms into green rust (slow oxidation) or into magnetite (rapid oxidation) [24]. The formation of green rust stage is followed by the appearance of lepidocrocite, which then transforms into end-products such as goethite $(\alpha-\mathrm{FeOOH})$, magnetite $\left(\mathrm{Fe}_{3} \mathrm{O}_{4}\right)$, maghemite $\left(\gamma-\mathrm{Fe}_{2} \mathrm{O}_{3}\right)$ and hematite $\left(\alpha-\mathrm{Fe}_{2} \mathrm{O}_{3}\right)$. The nature of end-products depends upon the environmental conditions $(\mathrm{pH}$, temperature, solution

\footnotetext{
* Corresponding author.

E-mail address: krawiec@agh.edu.pl (H. Krawiec).
} 

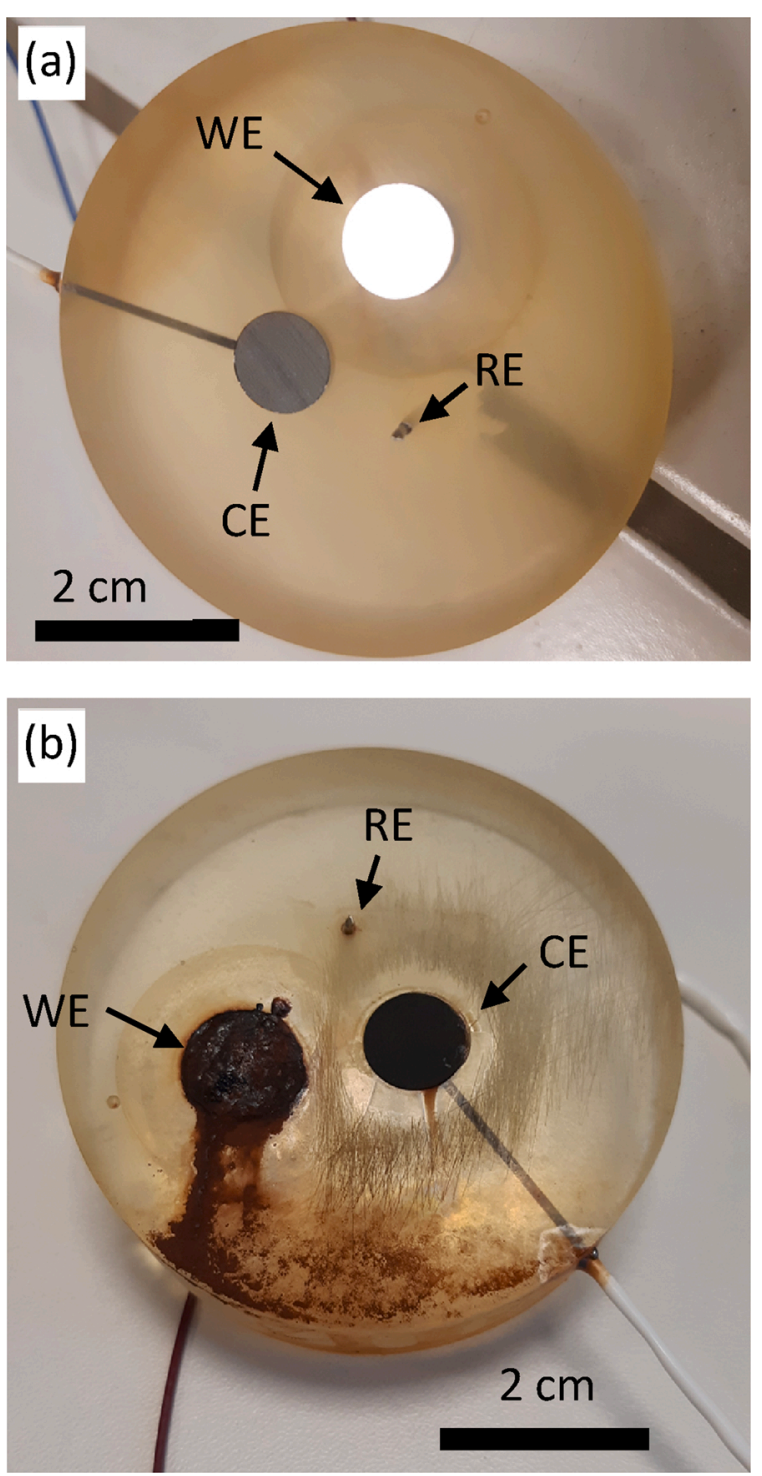

Fig. 1. Images of the specific cell $(\mathrm{WE}=$ working electrode, $\mathrm{RE}=$ reference electrode, $\mathrm{CE}=$ counter electrode) used to perform electrochemical measurements in the salt fog chamber: (a) after surface preparation and (b) after testing for 42 cycles.

composition and oxidation rate). In the presence of halogen ions $\left(\mathrm{Cl}^{-}\right.$or $\mathrm{F}^{-}$), akaganeite $(\beta-\mathrm{FeOOH})$ can be formed from green rust. Corrosion products play an important role in atmospheric corrosion processes. $\mathrm{Fe}^{2+}$ based compound may undergo oxidation whereas $\mathrm{Fe}^{3+}$ based compounds may undergo reduction (making the oxygen reduction reaction unnecessary and promotes oxidation processes).
In the present paper, the corrosion behaviour of ADI is studied under salt spray conditions for 42 wet / dry cycles $\left(0.05 \mathrm{M} \mathrm{NaCl}\right.$ at $30{ }^{\circ} \mathrm{C}, 0.4$ $\mathrm{mL} / \mathrm{h}$ ). Electrochemical measurements (OCP vs time measurements and polarisation curves) were performed in the salt spray chamber, at the beginning of each wet cycle. The morphology and composition of corrosion products was determined by means of field-emission scanning electron microscopy (FE-SEM/EDS) observations and micro-Raman experiments. The role of the ADI microstructure (studied by FE-SEM/EDS) and corrosion products in the corrosion processes is discussed.

\section{Experimental}

\subsection{Material, specimen and austempering heat treatment}

The chemical composition of the ductile iron (DI, pearlitic structure) which was used as initial alloy is C: 3.48 wt. $\%$, Mn: 0.63 wt. $\%$, Si: 2.58 wt.\%, P: 0.03 wt.\%, S: 0.017 wt.\%, Cr: 0.06 wt.\%, Ni: 0.04 wt.\%, Cu: 0.32 wt.\%, Mg: 0.054 wt.\%, Mo: 0.07 wt. $\%$, Ti: 0.015 wt.\%, Sn: 0.006 wt.\%, Pb: 0.001 wt.\%, V: 0.009 wt.\%, W: 0.038 wt.\%, Zn: 0.003 wt.\%. Liquid DI was poured into Y block molds. After solidification, the blocks were cut into cylinders (diameter $=10 \mathrm{~mm}$, length $=70 \mathrm{~mm}$ ). To obtain ADI samples, cylinders were placed in a salt bath furnace. A temperature of $900^{\circ} \mathrm{C}$ was first applied for $2 \mathrm{~h}$ (austenitizing), followed by $280^{\circ} \mathrm{C}$ for $10 \mathrm{~min}$ (austempering). Water cooling to room temperature was then carried out.

Prior to salt spray tests, ADI specimens were mechanically ground with silicon carbide ( $\mathrm{SiC}$ ) emery papers down to 4000 grit and polished with diamond pastes down to $1 \mu \mathrm{m}$. They were ultrasonically rinsed in ethanol between each step.

\subsection{Salt spray test}

Fig. 1 shows the three-electrode arrangement used in the electrochemical experiments. The counter electrode is a graphite carbon disk of very high purity (chemical composition: $99.997 \mathrm{wt} . \%$ C, $0.2 \mathrm{wt} . \% \mathrm{ppm}$ Al, 1 wt.\%ppm B, 0.05 wt.\%ppm Ca, 0.01 wt.\%ppm Cu, 0.2 wt.\%ppm $\mathrm{Fe}, 0.05$ wt.\%ppm Mg, 0.02 wt.\%ppm Na and 1 wt.\%ppm Si). Its surface area is $0.8 \mathrm{~cm}^{2}$. The pseudo reference electrode is a platinum wire (length $=2 \mathrm{~mm}$, diameter $=1 \mathrm{~mm}$ ) and the working electrode is ADI (surface area of $0.8 \mathrm{~cm}^{2}$ ). This three-electrode arrangement was embedded in an epoxy resin and placed in the salt spray chamber (Ascott S120iP) at a tilt angle of $5^{\circ}$.

The corrosion test consists of successive wet $(0.05 \mathrm{M} \mathrm{NaCl}, 0.4 \mathrm{~mL} / \mathrm{h})$ and dry periods. A cycle corresponds to a wet period $\left(12 \mathrm{~h}\right.$ at $\left.30{ }^{\circ} \mathrm{C}\right)$ followed by a dry one $\left(12 \mathrm{~h}\right.$ at $\left.30^{\circ} \mathrm{C}\right)$. The total number of cycles is 42 . Electrochemical measurements were performed for each cycle, $4 \mathrm{~h}$ after the onset of the wet period. The OCP measurement was first carried out for $900 \mathrm{~s}$ (acquisition frequency of $1 \mathrm{~Hz}$ ). Linear sweep voltammetry (LSV) measurements were then performed from $-1400 \mathrm{mV}$ up to +1000 $\mathrm{mV}$. at a potential scan rate of $3 \mathrm{mV} / \mathrm{s}$. The potentiostat/Galvanostat/EIS Analyzer Parstat 4000 (AMTEK Princeton Applied Research, USA) was used. 

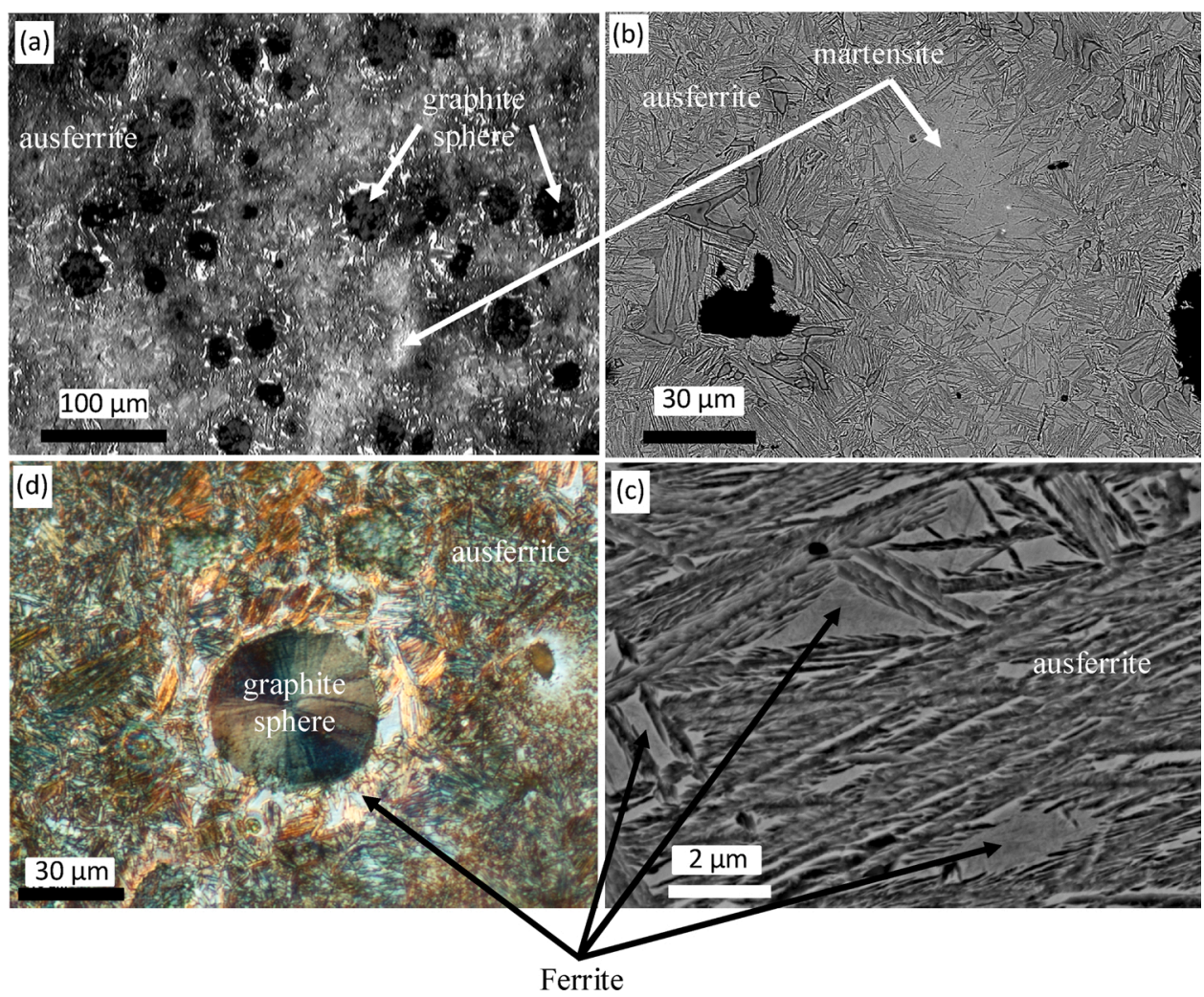

Fig. 2. (a-c) FE-SEM micrographs of ADI after etching in Nital solution for $5 \mathrm{~s}$. (d) Optical image of ADI after etching in the B-M reagent for $30 \mathrm{~s}$.

To validate the experimental procedure used, a preliminary test (not shown in the paper) was performed. Two identical samples were introduced into the salt spray chamber. During cycles 4 and 30, a polarization curve was plotted on only one of the two samples, $4 \mathrm{~h}$ after the start of the wet phase. As soon as this curve was stopped, two other polarization curves were plotted simultaneously on the two samples (the sample on which a curve has already been plotted and the so-called 'fresh' sample). These three curves were quantitatively compared (shape, values of current density for given applied potential and corrosion rates). It was found that for the experimental conditions selected in this paper, all the polarization curves are very close, indicating that repeatability is very good and changes induced by plotting these curves are very small. The same experiments were performed for the OCP measurements and the same conclusions were drawn. In addition, XRD experiments on the two samples did not revealed any changes in the corrosion products.

\subsection{FE-SEM/EDS observations}

The morphology and the chemical composition of the rust layer were studied at the microscale by using a field-emission type scanning electron microscope (JEOL $7600 \mathrm{~F}$ ) with an integrated electron dispersion spectrometer (FE-SEM/EDS).

\subsection{Micro-Raman spectroscopy measurements}

Micro-Raman spectra were recorded using a Renishaw inVia Raman microscope (backscattering geometry, $100 \times$ objective lens with numerical aperture 0.85 (Leica objective), $633 \mathrm{~nm}$ excitation laser (HeNe, spatial resolution $1 \mu \mathrm{m}), 1 \mathrm{~s}$ exposure time, 1000 accumulations and laser power reduced to $700 \mu \mathrm{W}$ by filters to avoid sample damage in the effect of local heating). When the laser power is too high ferrihydrite, lepidocrocite, magnetite, maghemite, siderite and wustite can form hematite by oxidation [26]. A Peltier-cooled CCD matrix detector was used for detection (diffraction gratings of 1800 grooves $\mathrm{mm}^{-1}$, resolution below $1.34 \mathrm{~cm}^{-1}$ ). The spectra were recorded in fast mode (fixed position of grating) according to ranges: i) the range of wavenumber $50-1300 \mathrm{~cm}^{-1}$ (main oxide bands); ii) the range of wavenumber $900-2000 \mathrm{~cm}^{-1}$ (the remaining oxide bands, graphite bands (D,G) as also band of amorphous carbon); iii) the range of wavenumber 2500-3250 $\mathrm{cm}^{-1}$ (graphite 2D band and the remaining second-order graphite bands). The spectrum model profile was determined by fitting each fragment of the spectrum after background correction with a pseudo-Voigt profile (linear combination of the Gaussian curve and Lorentzian curve) using Renishaw Wire ver. 3.4 software. 

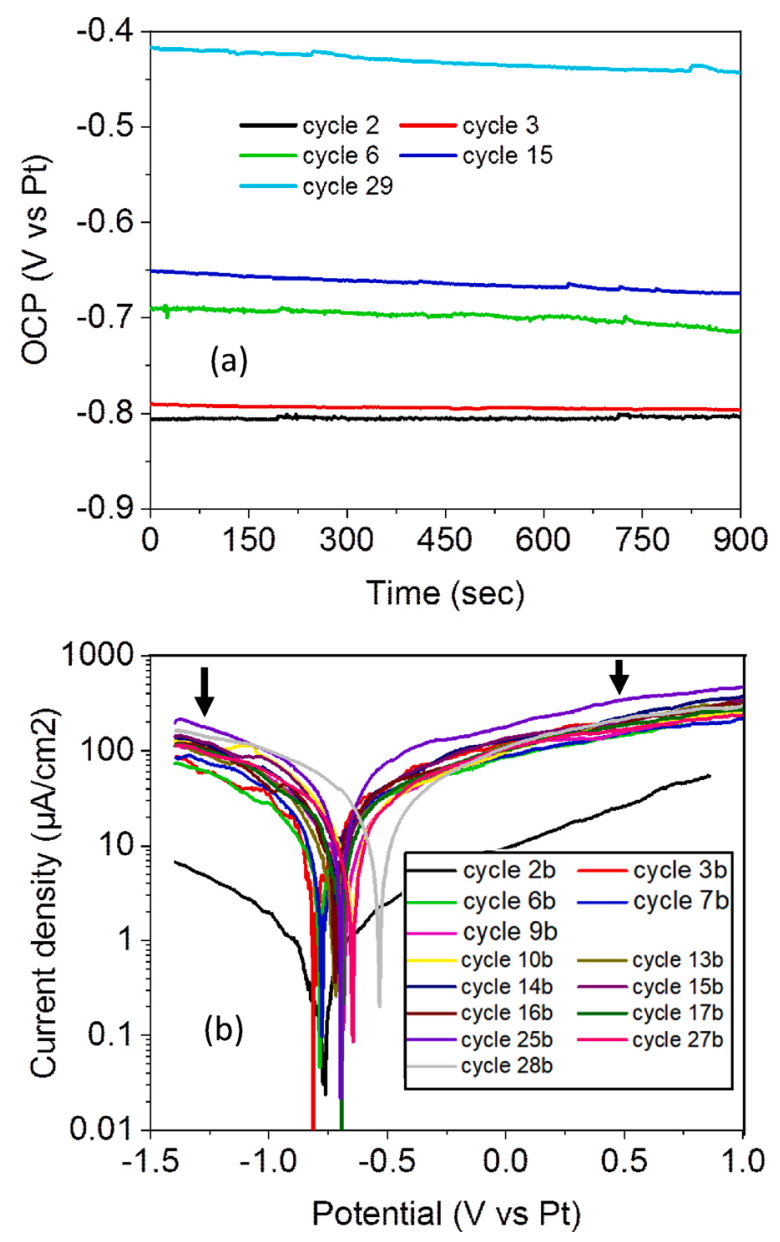

Fig. 3. (a) OCP of ADI vs time and (b) polarisation curves ( $3 \mathrm{mV} / \mathrm{s}$ ) of ADI for different cycles.

\section{Results and discussion}

Fig. 2(a-d) shows FE-SEM/EDS and optical images of ADI after etching. This microstructure was already analysed at the microscale in a previous work [7]. This was done by means of FE-SEM/EDS, X-ray diffraction (XRD) and microhardness tests. Graphite spheres are embedded in an 'ausferrite matrix' (Fig. 2(a,d)). This matrix consists of a mixture of ferrite plates (generally oriented perpendicularly to the surface) and high carbon austenite $\left(\gamma_{\mathrm{HC}}\right.$-phase) between them, Fig. $2(\mathrm{a}-\mathrm{d})$. FE-SEM/EDS analyses were performed in the ferrite plates oriented parallel to the surface (Fig. 2(c)): $6.7 \pm 0.6$ at.\% C, $6.9 \pm 0.8$ at.\% Si, 0.2 \pm 0.1 at. $\%$ Mn, $1.9 \pm 0.6$ at. $\%$ O, $84.3 \pm 0.8$ at. $\%$ Fe. During the ausferritic transformation, nucleation of ferrite plates occurs at the interface between graphite and austenite, Fig. 2(d). This site is privileged to
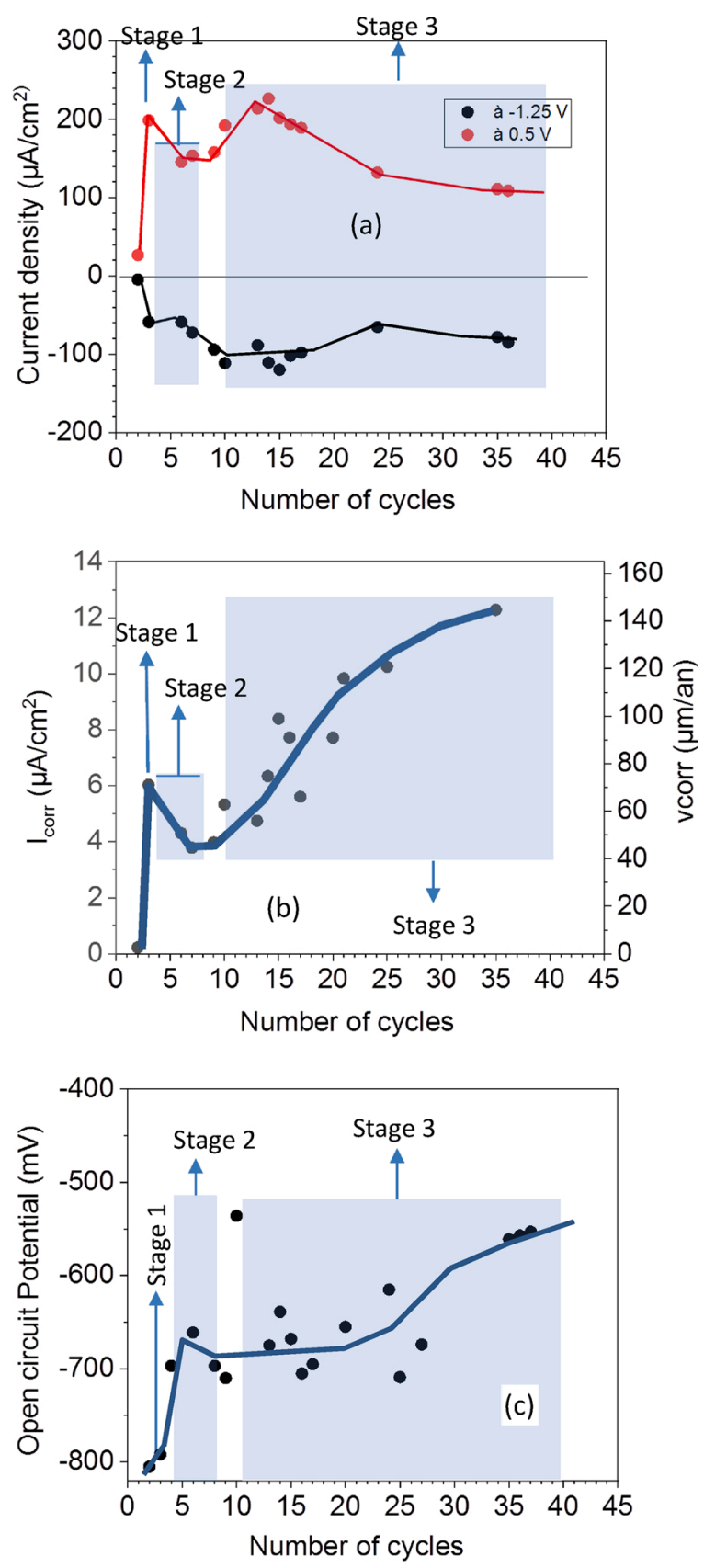

Fig. 4. Evolution vs the number of cycles of (a) current density at various applied potentials, (b) the corrosion current density and the corrosion rate and (c) the OCP. 

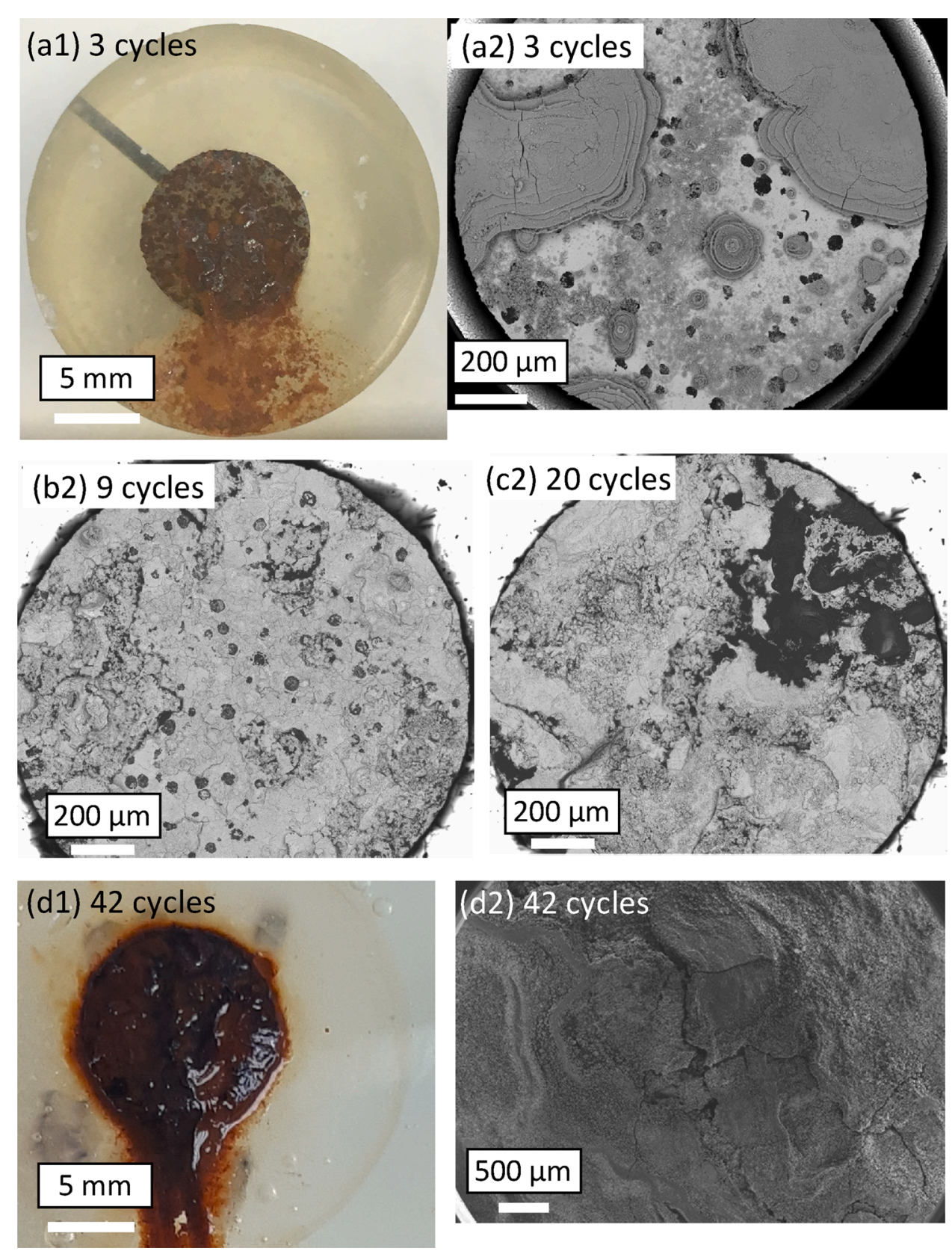

Fig. 5. (a-d) Surface observations of the ADI sample after various numbers of cycles : (1) = optical images and (2) = FE-SEM micrographs at low spatial resolution. 

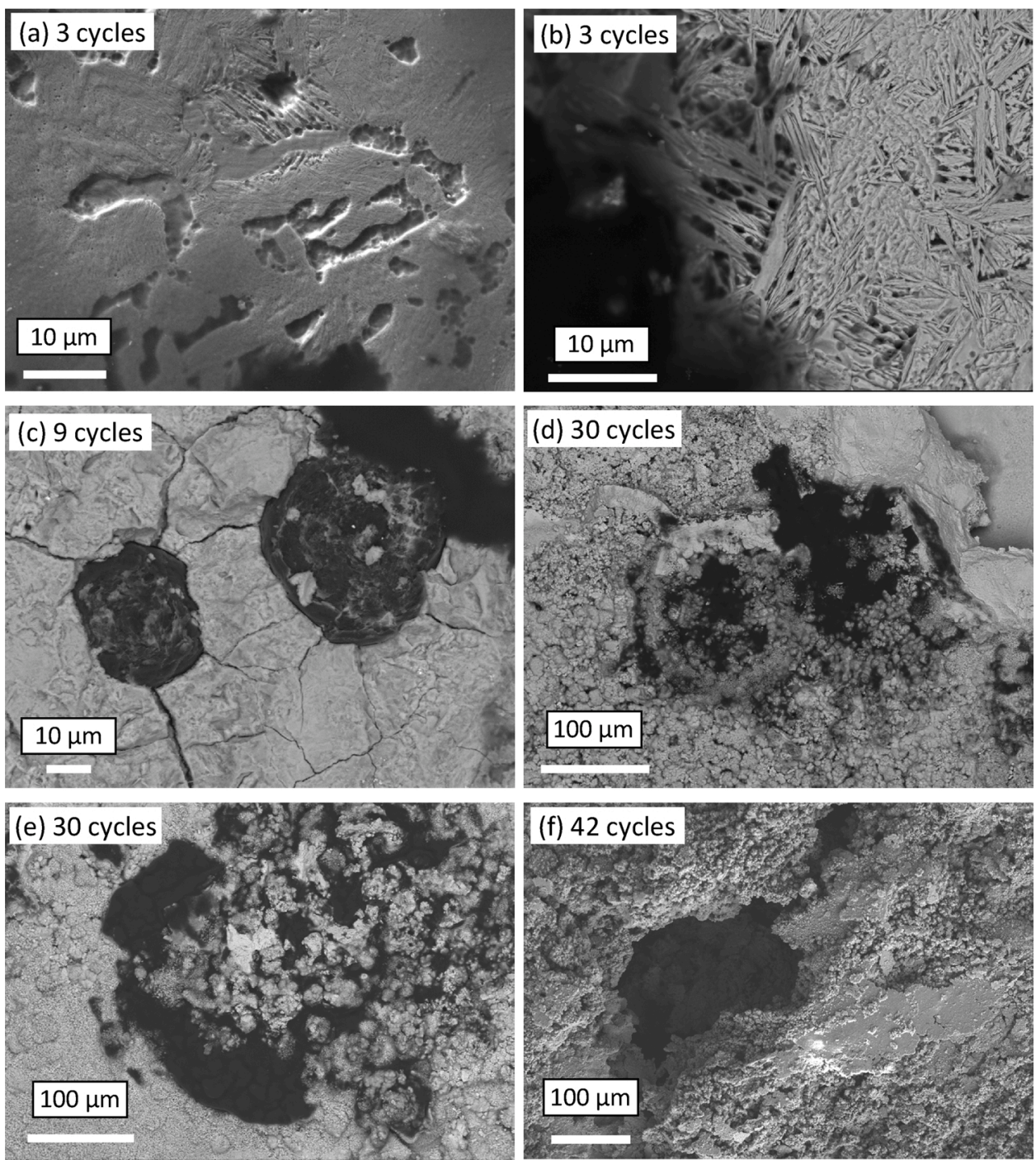

Fig. 6. (a-f) FE-SEM micrograph at high spatial resolution of the ADI sample after various numbers of cycles.

nucleate ferrite probably due to the highest concentration of elements favoring ausferritic transformation, i.e. silicon and nickel. These alloying elements $(\mathrm{Ni}, \mathrm{Si})$ reduce the solubility of carbon in austenite, and silicon additionally accelerates the diffusion of carbon in austenite [27]. These two effects promote nucleation and growth of ferrite plates. In addition, it should be added that the size of the precipitates is largely a function of the isothermal transformation temperature.

Martensite was also detected by means of optical observations and microhardness measurements [7], Fig. 2(a-b). Martensite results from the decomposition of a part of the $\gamma$-phase (that was not completely dissolved during tempering) during water cooling. EDS analyses in the martensite yields $11.2 \pm 0.9$ at. $\% \mathrm{C}, 3.4 \pm 0.1 \% \mathrm{Si}, 1 \pm 0.1 \% \mathrm{Mn}, 2.2 \pm$ $0.1 \% \mathrm{O}, 81.6 \pm 0.9 \% \mathrm{Fe}$. XRD revealed that the alloy is composed of 20 $\%$ of austenite and $80 \%$ of ferrite + martensite.
3.1. In-situ monitoring of the corrosion behaviour of ADI and surface observations

Fig. 3(a-b) shows the evolution of the OCP vs time and polarisation curves for different cycles. During the measurement period, the OCP was found to be stable and no transients were observed. Polarisation curves reveal the active behaviour of ADI under salt spray conditions (no passive range). Several electrochemical parameters were derived from these curves, namely the current density at $-1250 \mathrm{mV}$ (cathodic domain) and $+500 \mathrm{mV}$ (anodic domain), Fig. 4(a), the corrosion current density (Fig. 4(b)) and the average value of the OCP (Fig. 4(c)). The corrosion current density was determined from the polarisation resistance method [28]. The corrosion rate, $\mathrm{v}_{\text {corr }}$, was then determined using Eq. (1). 


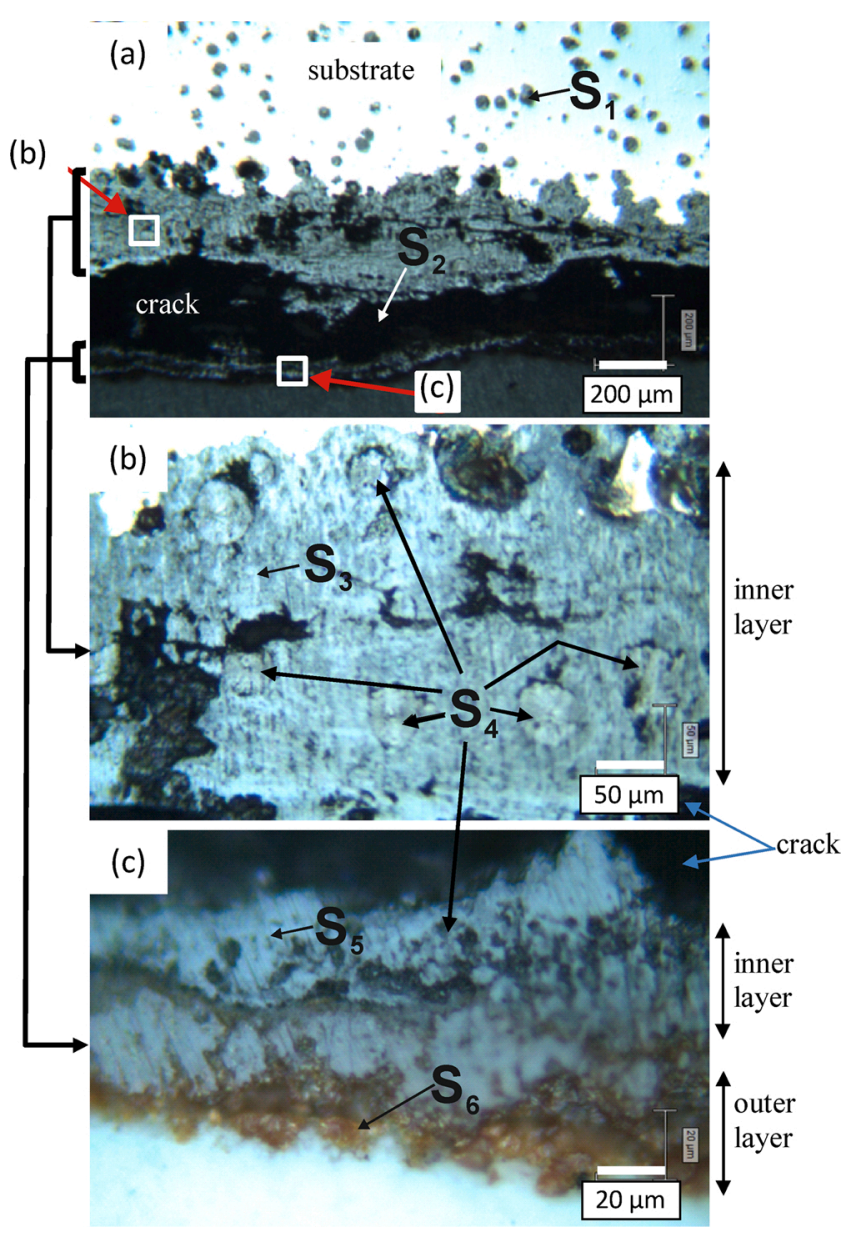

Fig. 7. (a) Optical images at low magnification of corrosion products. (b-c) Optical images at high magnification of sites located in (a) where micro-Raman measurements were performed (sites S2, S3, S5 and S6). Sites S1 and S4 correspond to graphite sphere in the substrate and in the corrosion products layer, respectively.

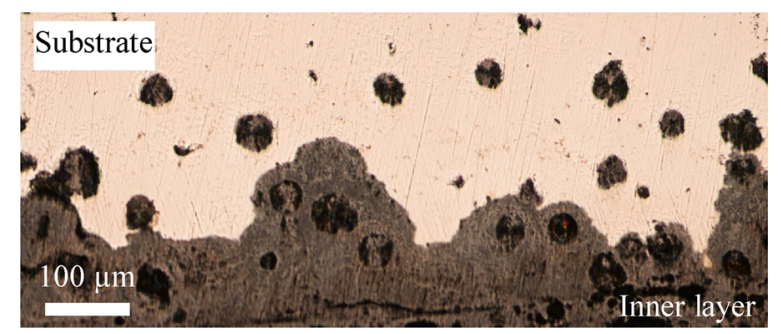

Fig. 8. Optical image of the interface between the substrate and the inner dense layer. $v_{\text {corr }}=j_{\text {corr }} \frac{M}{n F \rho}$

where $M$ is the molar mass $(M=55.8 \mathrm{~g} / \mathrm{mol}), \mathrm{j}_{\text {corr }}$ the corrosion current density $\left(\mathrm{A} / \mathrm{m}^{2}\right)$, $\mathrm{n}$ the number of electrons $(\mathrm{n}=2)$, $\mathrm{F}$ the Faraday's constant $(F=96485 \mathrm{C} / \mathrm{mol})$ and $\rho$ the density $\left(\rho=7.8 \times 10^{6} \mathrm{~g} / \mathrm{m}^{3}\right)$. Fig. $4(\mathrm{a}-\mathrm{c})$ shows that the electrochemical parameters vary significantly vs the number of cycles, indicating that the corrosion behaviour of ADI changes with time. To interpret these changes, optical and FE-SEM/EDS observations at different spatial resolution were carried out after 3, 9, 20, 30 and 42 cycles (Figs. 5 and 6).

Stage I (cycles \#1 - \#3). The current density in the anodic domain increases by one order of magnitude (from roughly $25 \mu \mathrm{A} / \mathrm{cm}^{2}$ in cycle \#1 up to $200 \mu \mathrm{A} / \mathrm{cm}^{2}$ in cycle \#3) whereas the current density in the cathodic domain increases up to a value of about $-50 \mu \mathrm{A} / \mathrm{cm}^{2}$ in cycle \#3, Fig. 4(a). In addition, the corrosion rate increases, from nearly $0 \mu \mathrm{m}$ /year (cycle \#1) up to $70 \mu \mathrm{m}$ /year (cycle \#3), Fig. 4(b). During these three cycles, the OCP is very low (of about $-800 \mathrm{mV}$, Fig. 4(c)). This tendency suggests that the surface is active.

Surface observations after cycle \#3 confirm this assumption. The microstructure of ADI is still visible in numerous sites, Fig. 5(a1-a2) and 6(a-b). EDS analyses indicate that these sites are slightly oxidized (low oxygen content): $14.9 \pm 0.2 \mathrm{at} . \% \mathrm{C}, 18.1 \pm 4.3 \% \mathrm{O}, 2.6 \pm 1 \% \mathrm{Na}, 2.9 \pm$ $0.5 \% \mathrm{Si}, 0.05 \pm 0.05 \% \mathrm{Cl}$ and $60.9 \pm 6.1 \% \mathrm{Fe}$. There is no difference level between the graphite spheres (not oxidized) and the "ausferrite" matrix, due to the inward diffusion of oxygen in the matrix. A high density of pits was observed in these sites, Fig. 6(a-b). As it was already observed in bulk electrolyte solutions [7], pits initiate in the ferrite. Therefore, pitting corrosion and inward oxidation of ADI mainly occur during stage I. However, in some sites, the surface is covered with a thick rust layer (Fig. 5(a2)), because of the outward diffusion of metallic ions. Numerous cracks are visible in this layer.

Stage II (cycles \#3 - \#9). By contrast to stage I, the "ausferrite" matrix of ADI is not visible on the whole surface. Only graphite spheres can be observed (Figs. 5(b2) and 6 (c)). They are not dissolved and can still act as cathodic sites. At the end of stage II, the entire surface (except graphite spheres) is strongly oxidized and a dense rust layer is present (Fig. 5(b2)). EDS analyses gives (performed on 4 different sites): $22.4 \pm$ 14.7at. \% C, $48.6 \pm 10.1 \%$ O, $0.3 \pm 0.1 \% \mathrm{Na}, 0.9 \pm 0.5 \% \mathrm{Si}, 0.3 \pm 0.2 \%$ $\mathrm{Cl}$ and $27.5 \pm 4.9 \% \mathrm{Fe}$. There is again no significant difference level between the rust layer and graphite spheres (Fig. 6(c)), because of inward diffusion of oxygen in the matrix. Small cracks are found around some graphite spheres, Fig. 6(c). The dense rust layer can help to prohibit further corrosion of ADI. This was confirmed from the evolution of the electrochemical parameters. Indeed, a slight decrease of the anodic current density (from 200 down to $150 \mu \mathrm{A} / \mathrm{cm}^{2}$, Fig. 4(a)), the corrosion rate (from 70 down to $40 \mu \mathrm{m} /$ year, Fig. 4(b)) and the corrosion potential (from -800 down to $-700 \mathrm{mV}$, Fig. 4 (c)) is observed when compared to the end of stage I.

Stage III (cycles \#10 - \#42). The OCP reaches a plateau and its value fluctuates around $-680 \mathrm{mV}$ (Fig. 4(c)). By contrast, the corrosion rate increases continuously and sharply (up to $140 \mu \mathrm{m} /$ year at the end of the test), Fig. 4(b). This increase of $v_{\text {corr }}$ is associated with the growth of 


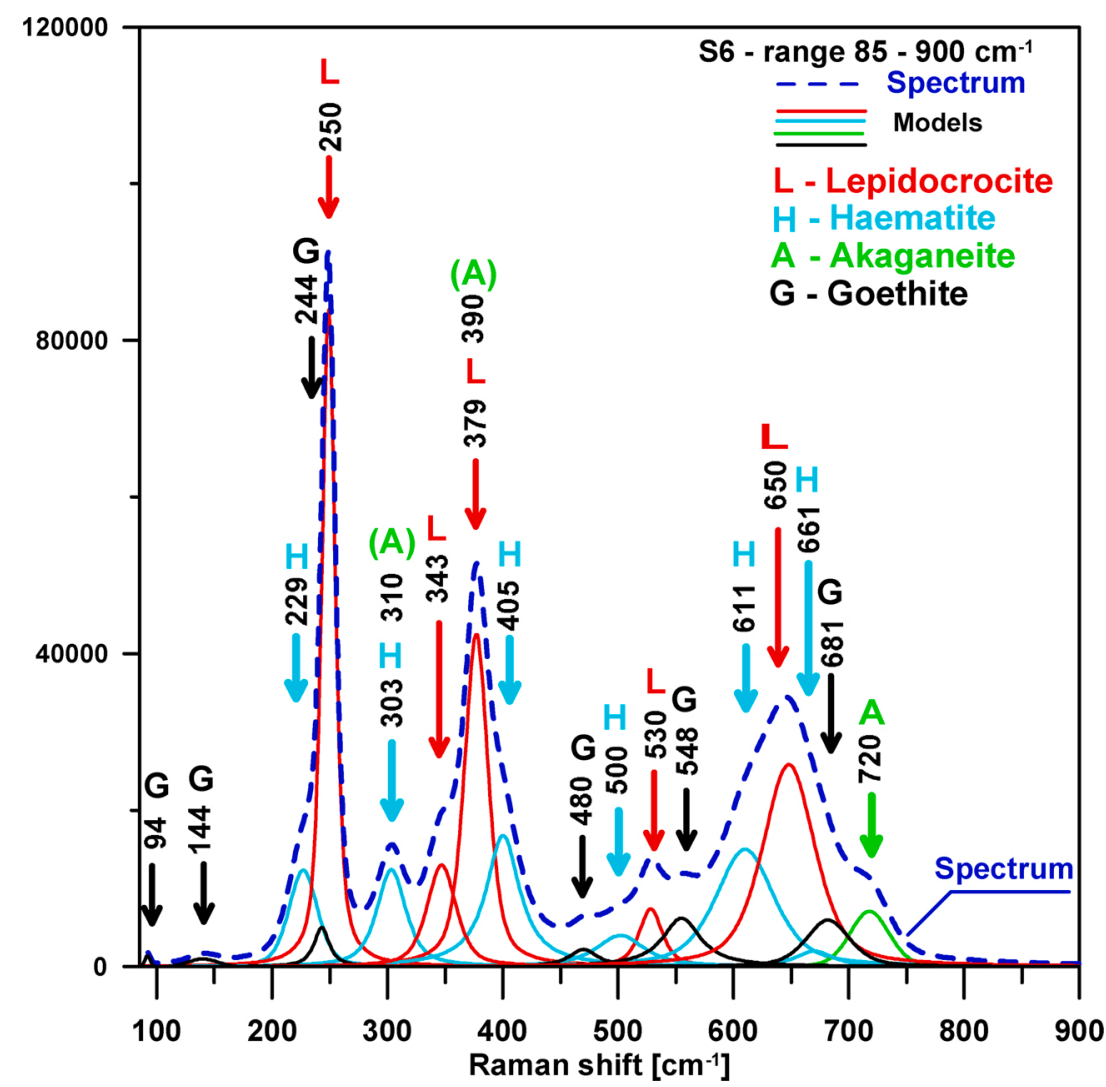

Fig. 9. Raman spectrum from site S6 in Fig. 7(c) (the spectrum range $85-900 \mathrm{~cm}^{-1}$ of Raman shift). The main phases are lepidocrocite (L), hematite (H) and akaganeite (A), with a small quantity of goethite (G).

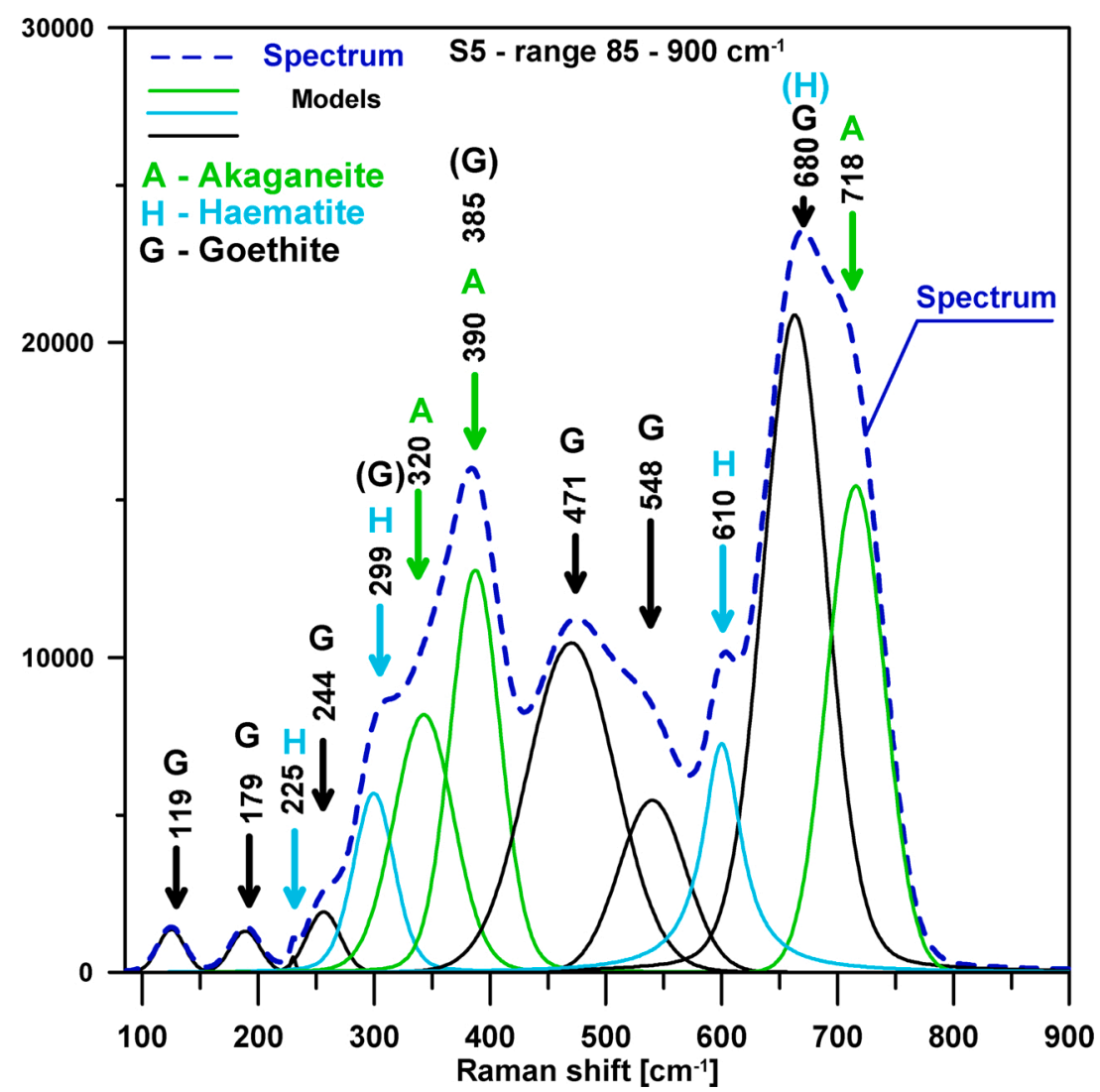

Fig. 10. Raman spectrum from site $S 5$ in Fig. 7 (c) (the spectrum range $85-900 \mathrm{~cm}^{-1}$ of Raman shift). The main phases are akaganeite (A), goethite (G) and hematite (H). 


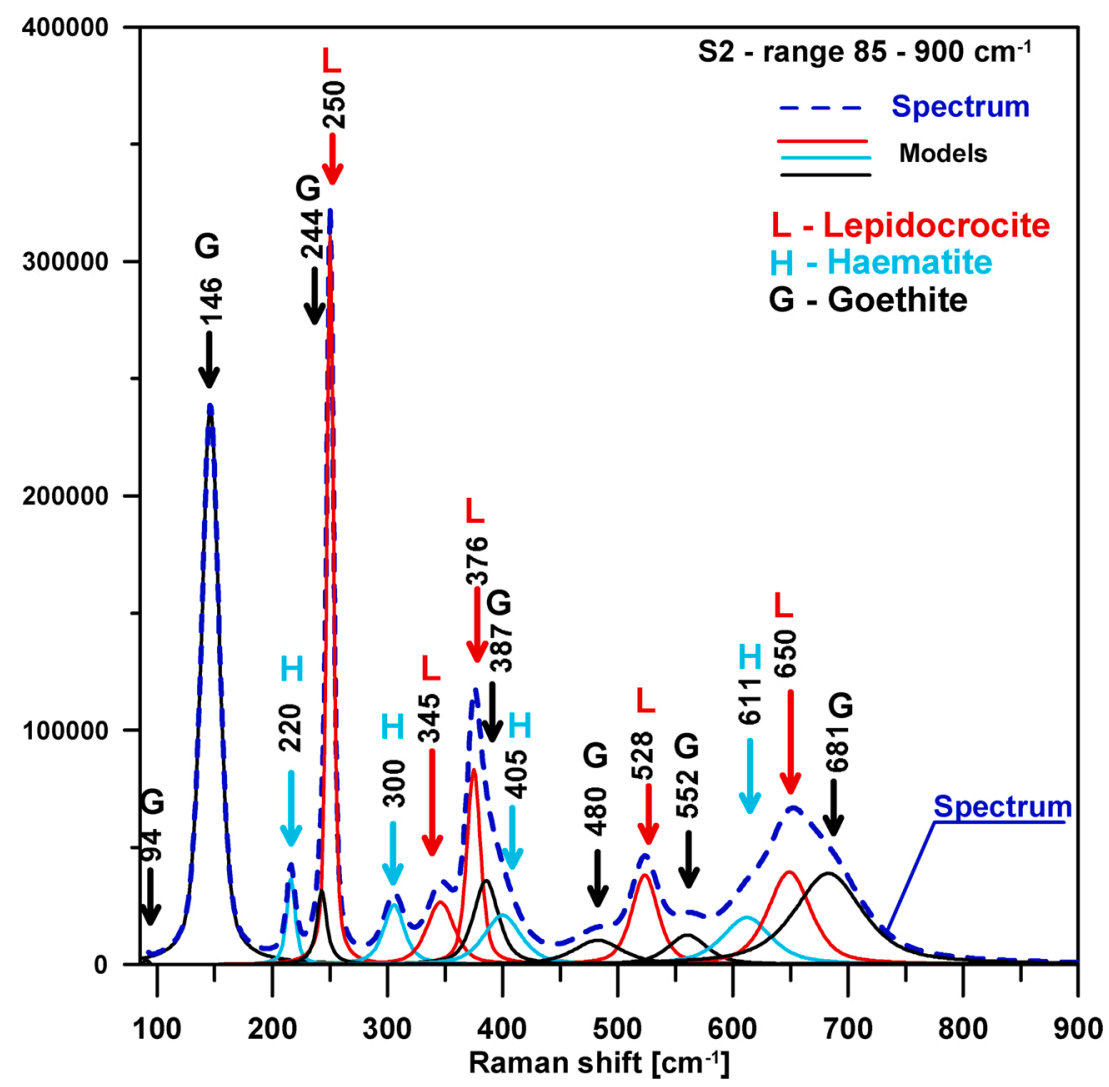

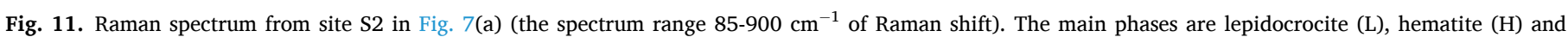
goethite (G).

a porous rust layer at the specimen surface, Figs. 5(d1-d2) and 6 (e-f). Pores and cracks are often visible in this layer (Fig. 6(f)). It was already demonstrated on steels that the porous rust can act as a water retention phase [29,30] and absorb the $\mathrm{Cl}^{-}$ions [31], which can actually accelerate the corrosion rate [32].

All graphite spheres are progressively covered with the porous rust layer (outward oxidation). between cycles \#20 and \#30, nearly all graphite spheres are covered (Fig. 5(c2) and 6(d-e)). This may explain why the current density in the cathodic domain starts to decrease slightly after roughly 20 cycles (Fig. 4(a)). Spheres are preferential sites for the cathodic reactions.

\subsection{Cross-section observations of the rust layer}

After corrosion tests, samples were cut using the Presi Mecatome T210 machine and embedded in an epoxy resin. Cross-section surfaces were ground and then smoothed (down to $1 \mu \mathrm{m}$ ). During this preparation step, most of the outer porous layer was removed. This layer is very brittle and has very low adhesion to the substrate.

Fig. 7(a) shows an optical cross-section image of the rust layer. It is composed of an inner dense layer (light grey in Fig. $7(\mathrm{a}-\mathrm{c})$ ) and an outer porous layer (brown color in Fig. 7(c)). A large crack is observed in the inner dense layer. Observations at high spatial resolution of this crack indicate that it is filled with corrosion products. The presence of cracks promotes the propagation of the electrolyte (with chloride ions and dissolved oxygen) inside the rust layer, promoting corrosion processes.

Numerous graphite spheres are found in the inner dense layer (sites S4 in Fig. 7(b-c)) confirming that this layer is associated to an inward growth mechanism (diffusion of oxygen to the metallic substrate). Micro-Raman measurements in spheres indicate that are not affected by corrosion processes. Indeed, excatly the same micro-Raman spectra were obtained on spheres located both in the metallic matrix and in the inner dense layer. On the other hand, the outer porous layer (most of which was removed during the preparation stage) is associated to an outward growth mechanism, Fig. 7(c).

The substrate / rust layer interface is very irregular, Fig. 7(a). High spatial resolution observations (Fig. 8) shows that the rust layer is preferentially formed around graphite spheres. As it was previously explained, these sites (around graphite spheres) are enriched in ferrite grains (Fig. 2(a,d)). This observation indicates that the ferrite is preferentially oxidized.

\subsection{Micro-Raman spectroscopy measurements in the rust layer}

Phase identification was performed in the rust layer using microRaman spectroscopy. Measurements were carried out on the crosssection surface, in the inner dense layer (sites S3 in Fig. 7(b) and S5 in Fig. $7(\mathrm{c})$ ) and in the outer porous layer (site S6 in Fig. 7(c)). 


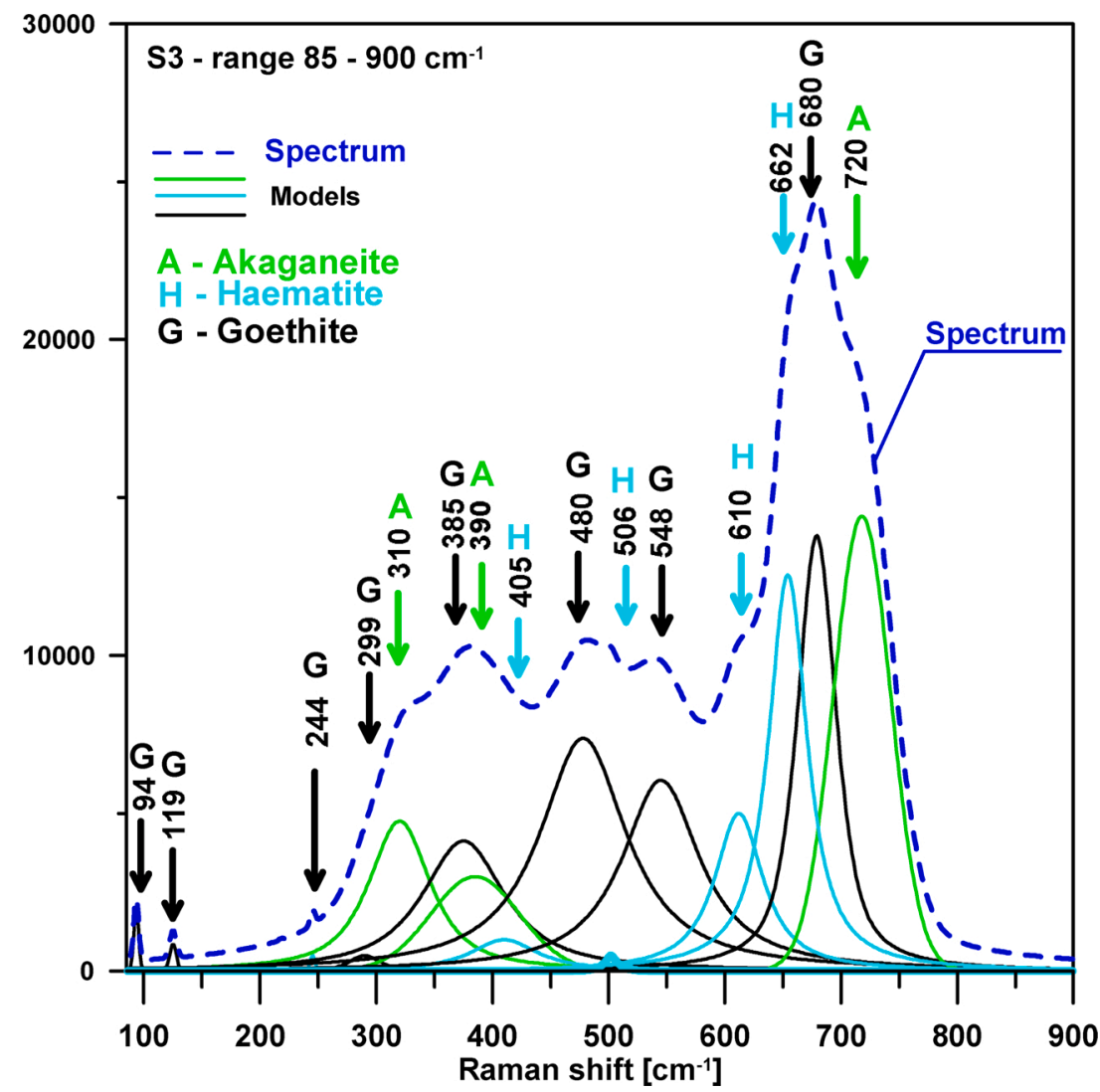

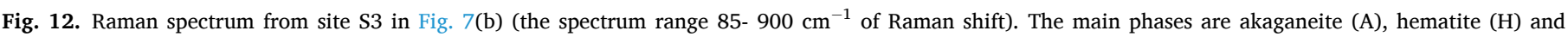
goethite (G).

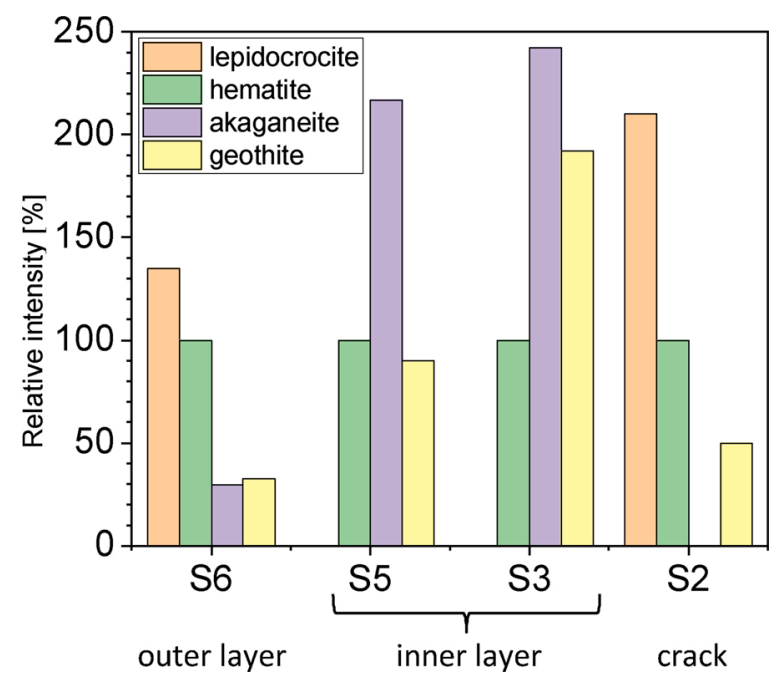

Fig. 13. Relative intensities of lepidocrocite (Raman shift: $250 \mathrm{~cm}^{-1}$ ), akaganeite (Raman shift: $718-720 \mathrm{~cm}^{-1}$ ) and goethite (Raman shift: $718-720 \mathrm{~cm}^{-1}$ ) bands in relation to intensities of hematite band (Raman shift: $610-611 \mathrm{~cm}^{-1}$ ) from different sites (Raman bands with minimal band overlap were chosen).
Measurements were also performed in the crack (site S2, Fig. 7(b)). Figs. 9-12 show the Raman spectra in these sites. The micro-Raman spectra were deconvoluted into individual bands using data from the literature: akageneite $\beta$ - $\mathrm{FeO}(\mathrm{OH})$ [33], ferrihydrite $\mathrm{Fe}_{5} \mathrm{HO}_{8} * 4 \mathrm{H}_{2} \mathrm{O}$ [34], goethite $\alpha-\mathrm{FeO}(\mathrm{OH})[24,35]$, hematite $\alpha-\mathrm{Fe}_{2} \mathrm{O}_{3}$ [33,26,24], lepidocrocite $\gamma$ - $\mathrm{FeO}(\mathrm{OH})$ [24], maghemite $\gamma-\mathrm{Fe}_{2} \mathrm{O}_{3}$ [26,36], magnetite $\mathrm{Fe}_{3} \mathrm{O}_{4}[26,37,38]$ and siderite $\mathrm{FeCO}_{3}[26]$.

Fig. 13 shows the relative intensities of Raman bands in relation to intensities of hematite band $610-611 \mathrm{~cm}^{-1}$ from different places in the rust layer after corrosion test. The Raman bands with minimal band overlap were chosen for each iron compound. The two sites located on both sides of the crack in the inner dense layer (S3 and S5 in Fig. 12) contain the same chemical compounds: goethite, akaganeite and hematite. Lepidocrocite was not present in the inner dense layer. Although the content of goethite (which is considered to be the most stable and protective compound [39-41]) is high in the inner dense layer, the content of other compounds (akaganeite + hematite) is also high. The ratio $\alpha / \gamma^{*}$ of the inner layer is lower than unity, indicating that the rust layer is not protective [42-44]. According to [43,44], the corrosion rate of weathering steels drops for values of $\alpha / \gamma^{*}$ greater than 1.5. These results are in good agreement with the high values of the corrosion rate found. The lowest content of goethite was found in the outer porous layer (S6 in Fig. 12). A large amount of lepidocrocite was detected, with a small amount of hematite and akaganeite. The largest amount of 


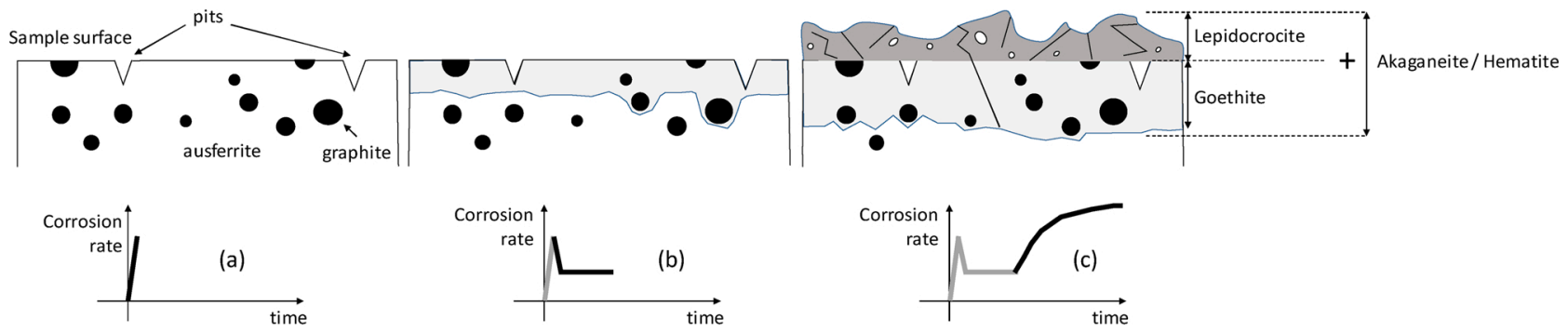

Fig. 14. (a-c) The schematic sketching for the corrosion mechanism of ADI under salt spray exposure.

lepidocrocite was found in the crack (site S2 in Fig. 12), with a small amount of hematite and goethite (no akaganeite). Lepidocrocite is semi-conducting and electrochemically active [39,45,46]. It can be electrochemically reduced into $\mathrm{Fe}^{\mathrm{II}}$ soluble species and/or soild $\mathrm{Fe}^{\mathrm{II}}$ phase. Therefore, the chemical composition was found to depend markedly on the sites analysed: inner dense layer, outer porous layer and cracks.

Fig. 14 shows the schematic sketching for the corrosion mechanism of ADI under salt spray exposure. During the very first cycles (Fig. 14 (a)), preferential dissolution of ferrite occurs. Slight oxidation of the ausferrite matrix is also observed. Iron dissolves into $\mathrm{Fe}^{2+}$ ions which then undergoes hydrolysis $\left(\mathrm{Fe}(\mathrm{OH})^{+}\right)$and oxidation $\left(\mathrm{Fe}^{3+}\right) . \mathrm{Fe}(\mathrm{OH})^{+}$can transform through rapid oxidation into lepidocrocite and slow oxidation into $\mathrm{Fe}_{\mathrm{a}}^{2+} \mathrm{Fe}_{\mathrm{b}}^{3+} \mathrm{O}_{\mathrm{x}}(\mathrm{OH})_{\mathrm{y}}$. Within this period, the corrosion rate increases significanty. With increasing number of cycles (Fig. 14(b)), strong oxidation of the ausferrite matrix takes place. Graphite spheres which are not oxidized were used as markers to show that oxidation is due to the inward diffusion of oxygen in the matrix. This compact layer protect ADI against corrosion and then the corrosion rate slightly decreases. From a certain number of cycles (depending of physical-chemical conditions at the specimen surface), a mixed oxidation process appears. The surface is covered with a thick rust layer (Fig. 14(c)), because of the outward diffusion of metallic ions, and the inner layer continues to grow (inward diffusion of oxygen). The outer layer contains numerous microcracks and pores. It acts as a water retention phase and absorbs the $\mathrm{Cl}^{-}$ ions. Cracks can also be formed in the inner layer. Then, the corrosion rate sharply increases. Lepidocrocite is found in the outer layer whereas goethite (end-product) is present in the inner layer. Hematite and akaganeite are found throughout the two layers.

\section{Conclusions}

The corrosion behavior of ADI was studied under cyclic salt spray exposure. The following conclusions can be drawn:

1) A specific electrochemical cell was used to perform in-situ electrochemical measurements (OCP vs time, polarisation curves) during the wet periods. From these mesurements, the corrosion rate was calculated using the resistance polarisation method.

2) A schematic sketching for the corrosion mechanism of ADI under salt spray exposure was then proposed. It was decomposed into three steps: (i) pitting corrosion of ferrite (very first cycles), (ii) inward oxidation of the ausferrite matrix associated with the formation of a dense inner layer and (iii) mixed oxidation of the matrix associated with the formation of a rust layer at the specimen surface.

3) Evolution of the corrosion rate was correlated with surface changes induced by corrosion in the different steps. In the next work, additional in-situ electrochemical measurements will be carried out to correlate the electrochemical data with the corrosion state of ADI. The purpose of the correlation is to identify the corrosion state simply through the observation/analysis of the electrochemical data so as to establish the guidelines for monitoring the corrosion state from in-situ electrochemical measurements.
4) Goethite (end-product) and lepidocrocite were found in the inner and outer layers, respectively (hematite and akaganeite in both layers).

5) The corrosion rate decreases when inward oxidation occurs (protective layer) and then sharply increases in the presence of the outer porous layer (mixed oxidation).

\section{Author statement}

H. Krawiec: project administration, realization of in-situ measurements, analysis of corrosion tests, writing, review, editing, conceptualization, methodology.

V. Vignal: realization of in-situ measurements, SEM observations, analysis of corrosion tests, writing, conceptualization, methodology.

J. Lelito: elaboration of ADI, heat treatments of ADI, microstructural analysis.

A. Krystianiak: realization of salt fog tests, optical observations, preparation of specific cells.

P. Ozga: Raman measurements and analysis.

\section{Declaration of Competing Interest}

The authors declare that they have no known competing financial interests or personal relationships that could have appeared to influence the work reported in this paper.

\section{References}

[1] B.V. Kovacs, On the terminology and structure of ADI, AFS Trans. 102 (1994) $417-420$.

[2] T.S. Shih, C.H. Chang, Z.D. Ou, Mechanical properties and microstructures of copper alloyed ADI, AFS Trans. 71 (1993) 857-872.

[3] P. Prasad Rao, Susil K. Putatunda, Influence of microstructure on fracture toughness of austempered ductile iron, Metall. Mater. Trans. 28A (1997) 1457-1470.

[4] E. Dorazil, Mechanical properties of austempered ductile iron, Foundry M\&T 7 (1986) 36-45.

[5] H. Krawiec, J. Lelito, E. Tyrała, J. Banaś, Relationships between microstructure and pitting corrosion of ADI in sodium chloride solution, J. Solid State Electrochem. 13 (2009) 935-942.

[6] H. Krawiec, B. Stypuła, J. Stoch, M. Mikołajczyk, Corrosion behaviour and structure of the surface layer formed on austempered ductile iron in concentrated sulphuric acid, Corros. Sci. 48 (2006) 595-607.

[7] H. Krawiec, V. Vignal, J. Lelito, A. Krystianiak, E. Tyrała, Influence of the heat treatment on the microstructure and corrosion resistance of austempered ductile iron (ADI), Arch. Metall. Mater. 65 (2020) 151-156.

[8] H. Krawiec, V. Vignal, J. Banaś, Macroscopic and local electrochemical studies of austempered ductile iron in perchlorate solutions, J. Electrochem. Soc. 153 (2006) B231-B237.

[9] H. Krawiec, Influence of corrosion inhibitors on the electrochemical behaviour of ADI in aqueous environments: local and macroscopic approaches, Adv. Mater. Sci. 7 (2007) 210-215.

[10] C.H. Hsu, K.T. Lin, Effects of copper and austempering on corrosion behavior of ductile Iron in 3.5 pct sodium chloride, Metall. Mater. Trans. 45A (2014) 1517-1523.

[11] X. Tang, C. Ma, X. Zhou, X. Lyu, Q. Li, Y. Li, Atmospheric corrosion local electrochemical response to a dynamic saline droplet on pure Iron, Electrochem. Comm. 101 (2019) 28-34.

[12] H. Simillion, O. Dolgikh, H. Terryn, J. Deconinck, Atmospheric corrosion modeling, Corros. Rev. 32 (2014) 73-100. 
[13] S. Song, Z. Chen, Initial corrosion of pure zinc under $\mathrm{NaCl}$ electrolyte droplet using a Zn-Pt-Pt three-electrode system, Int. J. Electrochem. Sci. 8 (2013) 6851-6863.

[14] X. Zhang, Y. Du, Electrochemical behavior of Cu underneath thin electrolyte film in atmosphere, J. Mater. Sci. Technol. 14 (1998) 547-550.

[15] C.M. Chen, T. Zhang, Y.W. Shao, C.F. Dong, Corrosion of pure magnesium under thin electrolyte films II -influence of thin electrolyte films on anodic process of pure magnesium corrosion, Corros. Sci. Protect. Technol. 21 (2009) 97-100.

[16] D. Boughrara, L. Hamadou, A. Kadri, N. Benbrahim, Thin electrolyte layer thickness effect on corrosion behaviour of invar in sulphate solutions, Corros. Eng. Sci. Technol. 42 (2007) 207-214.

[17] M. Ledvina, E.D. Rigney, The thin electrolyte layer approach to corrosion testing of dental materials - characterization of the technique, Biomater. 19 (1998) 2201-2207.

[18] E. Remita, E. Sutter, B. Tribollet, F. Ropital, X. Longaygue, C. Taravel-Condat, N. Desamais, A thin layer cell adapted for corrosion studies in confined aqueous environments, Electrochim. Acta 52 (2007) 7715-7723.

[19] H.P. Wang, S.C. Ding, J. Zhu, Z. Zhang, J.Q. Zhang, C.N. Cao, Corrosion behavior of 907 steel under thin electrolyte layers of artificial seawater, J. Cent. South Univ. 22 (2015) 806-814.

[20] Y.L. Cheng, Z. Zhang, F.H. Cao, J.F. Li, J.Q. Zhang, J.M. Wang, C.N. Cao, A study of the corrosion of aluminum alloy 2024-T3 under thin electrolyte layers, Corros. Sci. 46 (2004) 1649-1667.

[21] R.E. Melchers, Long-term corrosion of cast irons and steel in marine and atmospheric environments, Corros. Sci. 68 (2013) 186-194.

[22] N.K. Tewary, A. Kundu, R. Nandi, J.K. Sahb, S.K. Ghosh, Microstructural characterisation and corrosion performance of old rail way girder bridge steel and modern weathering structural steel, Corros. Sci. 113 (2016) 57-63.

[23] S. Guo, R. Si, Q. Dai, Z. You, Y. Ma, J. Wang, A critical review of corrosion development and rust removal techniques on the structural/environmental performance of corroded steel bridges, J. Clean. Prod. 233 (2019) 126-146.

[24] S.J. Oh, D.C. Cook, H.E. Townsend, Characterization of iron oxides commonly formed as corrosion products on steel, Hyperfine Interact. 112 (1998) 59-65.

[25] R.M. Cornell, U. Schwertmann, The Iron Oxides, John-Wiley VCH, Weinheim, 2003.

[26] M. Hanesch, Raman spectroscopy of iron oxides and (oxy)hydroxides at low laser power and possible applications in environmental magnetic studies, Geophys. J. Int. 177 (2009) 941-948.

[27] C.H. Chang, T.S. Shih, Study on isothermal transformation of austempered ductile Iron, AFS Trans. 102 (1994) 357-365.

[28] J.R. Scully, Polarization resistance method for determination of instantaneous corrosion rates, Corrosion 56 (2000) 199-218.

[29] W. Zhang, C. Cai, F. Pan, Y. Zhang, Fatigue life estimation of existing bridges under vehicle and non-stationary hurricane wind, J. Wind Eng. Ind. Aerodyn. 133 (2014) $135-145$.

[30] X. Zhang, S. Yang, W. Zhang, H. Guo, X. He, Influence of outer rust layers on corrosion of carbon steel and weathering steel during wet-dry cycles, Corros. Sci. 82 (2014) 165-172.
[31] E. Burger, M. Fénart, S. Perrin, D. Neff, P. Dillmann, Use of the gold markers method to predict the mechanisms of iron atmospheric corrosion, Corros. Sci. 53 (2011) 2122-2130.

[32] S. Hoerlé, F. Mazaudier, P. Dillmann, G. Santarini, Advances in understanding atmospheric corrosion of iron. II. Mechanistic modelling of wet-dry cycles, Corros. Sci. 46 (2004) 1431-1465.

[33] L. Bellot-Gurlet, D. Neff, S. Réguer, J. Monnier, M. Saheb, P. Dillmann, Raman studies of corrosion layers formed on archaeological irons in various media, J. Nano RES-SW 8 (2009) 147-156.

[34] J. Kassim, T. Baird, J.R. Fryer, Electron Microscope studies of iron corrosion products in water at room temperature, Corros. Sci. 22 (1982) 147-158.

[35] RRUFF database: Goethite R120086, University of Arizona, 2019.

[36] G.V.M. Jacintho, P. Corio, J.C. Rubim, Surface-enhanced Raman spectra of magnetic nanoparticles adsorbed on a silver electrode, J. Electroanal. Chem. 603 (2007) 27-34.

[37] D.L.A. de Faria, S. Venancio Silva, M.T. de Oliveira, Raman microspectroscopy of some iron oxides and oxyhydroxides, J. Raman Spectrosc. 28 (1997) 873-878.

[38] O.N. Shebanova, P. Lazor, Raman spectroscopic study of magnetite $\left(\mathrm{FeFe}_{2} \mathrm{O}_{4}\right)$ : a new assignment for the vibrational spectrum, J. Solid State Chem. 174 (2003) 424-430.

[39] G.P. Singh, A.P. Moon, S. Sengupta, G. Deo, S. Sangal, K. Mondal, Corrosion behavior of IF steel in various media and its comparison with mild steel, J. Mater. Eng. Perform. 24 (2015) 1961-1974.

[40] V. Lair, H. Antony, L. Legrand, A. Chaussé, Electrochemical reduction of ferric corrosion products and evaluation of galvanic coupling with iron, Corros. Sci. 48 (2006) 2050-2063.

[41] T. Okada, Y. Ishii, T. Mizoguchi, I. Tamura, Y. Kobayashi, Y. Takagi, S. Suzuki, H. Kihira, M. Itou, A. Usami, Mossbauer studies on particle volume distribution of $\alpha-\mathrm{FeOOH}$ in rust formed on weathering steel, Jpn. J. Appl. Phys. 39 (2000) 3382-3391.

[42] T. Kamimura, S. Hara, H. Miyuki, M. Yamashita, H. Uchida, Composition and protective ability of rust layer formed on weathering steel exposed to various environments, Corros. Sci. 48 (2006) 2799-2812.

[43] M. Yamashita, T. Misawa, Recent Progress in the Study of Protective Rust-layer Formation on Weathering Steel, Proceedings Corrosion' 98, Technical Publication, San Diego, 1998, p. 357.

[44] J. Alcántara, D. de la Fuente, B. Chico, J. Simancas, I. Díaz, M. Morcillo, Marine atmospheric corrosion of carbon steel: a review, Materials 10 (2017) 406.

[45] J. Monnier, S. Réguer, E. Foy, D. Testemale, F. Mirambet, M. Saheb, P. Dillmann, I. Guillot, XAS and XRD in situ characterisation of reduction and reoxidation processes of iron corrosion products involved in atmospheric corrosion, Corros. Sci. 78 (2014) 293-303.

[46] T. Kamimura, S. Nasu, Mössbauer spectroscopic study of rust formed on a weathering steel exposed for 15 years in an industrial environment, Mater. Trans. JIM 41 (2000) 1208-1215. 